Discussion Paper No. 13-007

\title{
Modeling Technological Change in Economic Models of Climate Change: A Survey
}

Andreas Löschel and Michael Schymura

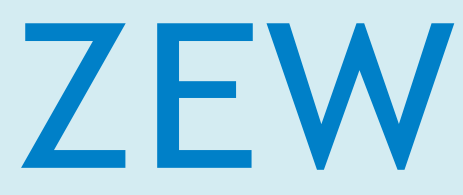

Zentrum für Europäische Wirtschaftsforschung $\mathrm{GmbH}$ Centre for European Economic Research 
Discussion Paper No. 13-007

\title{
Modeling Technological Change in Economic Models of Climate Change: A Survey
}

\author{
Andreas Löschel and Michael Schymura
}

Download this ZEW Discussion Paper from our ftp server:

http://ftp.zew.de/pub/zew-docs/dp/dp13007.pdf

Die Discussion Papers dienen einer möglichst schnellen Verbreitung von neueren Forschungsarbeiten des ZEW. Die Beiträge liegen in alleiniger Verantwortung der Autoren und stellen nicht notwendigerweise die Meinung des ZEW dar.

Discussion Papers are intended to make results of ZEW research promptly available to other economists in order to encourage discussion and suggestions for revisions. The authors are solely responsible for the contents which do not necessarily represent the opinion of the ZEW. 


\section{ExeCUTIVE SUMMARY}

The assessment of climate change mitigation policies mainly depends on three not mutually exclusive modeling decisions: First, the chosen discount rate, since costs are incurred today and long-term benefits occur in the future. A low (high) discount rate favors immediate (delayed) action. Second, the uncertainties related to the problem of climate change. This debate was revived by the literature dealing with Martin Weitzman's "dismal theorem", stating that the unknown unknowns could be too large for cost-benefit analysis of long-term climate policy measures. Third, the treatment of technological change in economic modeling of climate policy.

Climate change, climate policy measures and technological change are highly intertwined matters. In general, the close relationship lies in negative and positive economic externalities. On the level of an individual firm as well as on a more global scale, pollution and climate change are negative externalities. On the other hand, the generation of knowledge represents a positive externality. The appropriate modeling of both is a crucial decision each modeler has to make. Many empirical studies have demonstrated the sensitivity of long-term analysis to assumptions about technological change. Most economic modeling was done under the assumption of exogenous technological change. These models are unable to capture and examine important links between policy and technical change. The wider literature acknowledged that technical change is not autonomous and that it is possible to identify processes which are responses to market conditions, expectations and governmental regulatory standards. To capture these developments, models incorporating endogenous technological change were developed, but the empirical base for the linkage between environmental policy and technical change was weak. In the past few years, significant improvements in the description of technological progress in climate policy assessment models have been achieved.

The purpose of this paper is threefold: First, we want to sketch the different options for modeling technological change on both a microeconomic and macroeconomic level, where our main focus will lie on large-scale macroeconomic models. Second, we want to give an overview of the different models surrounding climate change and energy economics. How is technological change implemented in the models? How does this affect the results? Which efforts have been made to endogenize the technological progress previously treated as exogenous? And finally we want to give a brief discussion of open research issues.

Although many problems associated with modeling technological change as exogenous have been resolved, numerous questions still remain unanswered. As technological change is an uncertain phenomenon, these uncertainties have to be incorporated in large-scale models more carefully. This holds particularly true for major innovations. Another important dimension of technical change that has to be taken into account is the potential for path-dependency, inertias and lock-in situations. Environment-energy-economy models can account for such effects by a careful inclusion of learning-by-doing, time lags, assumptions about the diffusion rates of innovations and directed (or biased) technological change. A further important aspect of the innovation process not appropriately accounted for is the heterogeneity of firms, as different firms respond differently to environmental policies. 


\section{DAS WiChtigste IN KÜRZE}

Die Bewertung von klimapolitischen Maßnahmen hängt im Wesentlichen von drei Entscheidungen des Ökonomen ab: Zum einen spielt die gewählte Diskontierungsrate eine bestimmende Rolle, da die Kosten einer klimapolitischen Maßnahme heute anfallen, die Nutzen allerdings erst in der fernen Zukunft realisiert werden. Eine niedrige (hohe) Diskontrate bevorzugt rasches (verzögertes) Handeln. Eine zweite wichtige Entscheidung betrifft die adäquate Modellierung von großen Unsicherheiten die mit dem Problem des Klimawandels einhergehen. Geprägt wurde die Debatte um diese Unsicherheiten von der Literatur um Martin Weitzman's ,dismal theorem". Dieses besagt, dass die unbekannten Risiken des Klimawandels zu groß seien für eine übliche Kosten-Nutzen-Analyse. Für dieses Papier ist die dritte zu treffende Entscheidung von zentraler Rolle: Wie soll technologischer Wandel in ökonomischen Modellen bestmöglich abgebildet werden?

Klimawandel, klimapolitische Maßnahmen und technologischer Fortschritt sind hochgradig miteinander verwoben. Grundsätzlich ist diese enge Beziehung durch positive und negative Externalitäten begründet. Aus der Perspektive einer einzelnen Firma, aber auch auf gesamtwirtschaftlicher Ebene, stellen Verschmutzung und der Klimawandel eine negative Externalität dar. Dem gegenüber steht die positive Externalität des technologischen Fortschritts. Empirische Studien haben die Sensitivität von langfristigen Analysen hinsichtlich der Modellierung von technologischem Wandel belegt. Die meisten Modelle nehmen an, dass der technologische Fortschritt exogen passiert, d.h. eine reine Funktion der Zeit ist. Diese Studien können das Zusammenspiel aus politischen Entscheidungen und technologischem Fortschritt nicht abbilden. Die ökonomische Literatur ist sich weitestgehend einig, dass technologischer Fortschritt nicht autonom „passiert“ und das es möglich ist, die treibenden Kräfte (z.B. Erwartungsbildung, politische Regulierung, Marktbedingungen) zu identifizieren. Modelle, die den technologischen Fortschritt als endogen berücksichtigen wurden entwickelt, aber die empirische Grundlage um das Zusammenspiel von Politik und Technologie zu modellieren war anfangs sehr dünn. In den vergangenen Jahren fanden aber signifikante Verbesserungen bei der Beschreibung und Implementierung des technologischen Fortschritts statt.

Dieses Arbeit hat drei Ziele: Zum einen wollen wir die verschiedenen Modellierungsmöglichkeiten diskutieren und legen den Fokus dabei auf makroökonomische Modelle. Zweitens, wollen wir einen Überblick über die gängigen Modelle und deren Vorgehensweise bei der Implementierung des technologischen Fortschritts geben. Abschließend diskutieren wir Bereiche, bei denen weiterer Forschungsbedarf besteht. Obwohl einige Probleme im Zusammenhang mit der Modellierung des technischen Wandels gelöst wurden, sind viele Fragen noch ungeklärt. Da der technologische Fortschritt an sich ein unsicherer Prozess ist, müssen diese Unsicherheiten in makroökonomischen Modelle besser berücksichtigt werden. Dies gilt insbesondere für weitreichende Innovationen. Eine weitere Dimension die besser abgebildet werden sollte, ist die Modellierung von Pfadabhängigkeiten und „Lock-in“-Situationen. Darüber hinaus, verwenden viele Modelle ad-hoc Annahmen bezüglich entscheidender Parameter wie z.B. Substitutionselastizitäten. Eine weitere Facette im Innovationsprozess die bislang unzureichend berücksichtigt wurde ist die Heterogenität von einzelnen Firmen da diese unterschiedlich auf Klimapolitik reagieren. 


\title{
Modeling Technological Change in Economic Models of Climate Change: A Survey
}

\author{
Andreas Löschel* and Michael Schymura ${ }^{\dagger}$
}

— January 30, 2013

\begin{abstract}
Summary - The assessment of climate change mitigation policies through economic modeling depends crucially on assumptions under which technological change has been incorporated in the model. Earlier climate-energy-economics modeling attempts heavily relied on the assumption of exogenous technological change. In this case, technological change is a function solely of time. However, such an approach seems insufficient, especially given developments in other fields of economic research that have helped to explain in more detail the process of technological change. A lot of research has been done hence on endogenizing technological change in large-scale models. The purpose of this paper is to summarize these efforts. We describe different model types and their treatment of exogenous technological change (autonomous energy efficiency improvements and backstop technologies) and endogenous technological change (including price inducement, learning-by-doing, investments in R \& D and directed technical change). We conclude with some open questions and suggestions for future research.
\end{abstract}

Keywords: Exogenous Technical Change, Endogenous Technological Change, Price inducement, Learning-by-doing, Directed Technical Change, Modeling

JEL-Classification: C50, C68, O30, Q25

${ }^{*}$ Centre for European Economic Research (ZEW), L7,1, D-68161 Mannheim, Germany; Email: loeschel@zew.de.

${ }^{\dagger}$ Centre for European Economic Research (ZEW), L7,1, D-68161 Mannheim, Germany; Email: schymura@zew.de. 


\section{Contents}

I Introduction $\quad 1$

II Technological Change and Economic Modeling 2

A Bottom-Up Modeling . . . . . . . . . . . . . . . 2

B Top-Down Approaches ..................... 3

III Exogenous Technological Change $\quad 4$

A Autonomous Energy Efficiency Improvement . . . . . . . . . . . . . . . 4

B Backstop Technologies ................. 6

$\begin{array}{ll}\text { IV Endogenous Technological Change } & \mathbf{7}\end{array}$

A Technological Change in Large-Scale and Aggregated Environmental

Models . . . . . . . . . . . . . . . . 7

Price-Induced Technological Change ......... 7

Directed Technological Change . . . . . . . . . . . . 9

Learning-by-doing . . . . . . . . . . . . . . 10

Research \& Development . . . . . . . . . . . 13

$\begin{array}{ll}\text { V Conclusion } & 16\end{array}$

Appendix A: Overview of the Studies $\quad 26$ 


\section{INTRODUCTION}

The assessment of climate change mitigation policies mainly depends on three not mutually exclusive modeling decisions: First, the chosen discount rate, since costs are incurred today and long-term benefits occur in the future. ${ }^{1}$ A low (high) discount rate favors immediate (delayed) action. Second, the uncertainties related to the problem of climate change. This debate was revived by the literature dealing with Martin Weitzman's "dismal theorem", stating that the unknown unknowns could be too large for cost-benefit analysis of long-term climate policy measures. ${ }^{2}$ Third, the treatment of technological change in economic modeling of climate policy. ${ }^{3}$

Climate change, climate policy measures and technological change are highly intertwined matters. In general, the close relationship lies in negative and positive economic externalities. On the level of an individual firm as well as on a more global scale, pollution and climate change are negative externalities and "must be regarded as market failure on the greatest scale the world has seen" (Stern, 2006, p. 27). On the other hand, the generation of knowledge represents a positive externality. ${ }^{4}$ Hence Adam Smith's famous invisible hand allows too much of the negative externality of pollution and provides too little of the positive externality of new technology (Popp et al., 2009). The appropriate modeling of both is a crucial decision each modeler has to make. Many empirical studies have demonstrated the sensitivity of long-term analysis to assumptions about technological change. In the 1990s most economic modeling was done under the assumption of exogenous technological change simply happening. These models are unable to capture and examine important links between policy and technical change. So taking technical change as given could be an oversimplification of this complex topic, leading to precipitate conclusions. The wider literature acknowledged that technical change is not autonomous and that it is possible to identify processes (such as governmental research and development spending, private sector investments, economies of scale) which are responses to market conditions, expectations and governmental regulatory standards (Grubb et al., 2002). Important insights from innovation research can explain how innovations occur and new technologies diffuse. These insights are of high importance since they may affect the optimal degree, nature and timing of abatement measures. To

\footnotetext{
${ }^{1}$ For an summary of the discounting debate in climate change economics, mainly surrounding the cost-benefit analysis conducted by Sir Nicholas Stern (Stern, 2006) and William Nordhaus (Nordhaus, 2007), see Dasgupta (2008).

${ }^{2}$ Baker et al. (2008b) survey the literature on the uncertainty issues of technological change. Ackerman et al. (2009) survey Integrated Assessment Models of Climate Change and their handling of catastrophic climate change. For a general discussion of the "dismal theorem" and the implications of catastrophic risk see Buchholz and Schymura (2012).

${ }^{3}$ Jacoby et al. (2006), for instance, perform a sensitivity analysis of structural parameters of their MIT-EPPA model. They conclude that assumptions with respect to technical progress such as the elasticity of substitution between energy and value added, vintage parameters, autonomous energy efficiency improvement and labor productivity are the main drivers of the modeling results.

${ }^{4}$ Knowledge often has the character of a public good, even more if this knowledge is general und usable by many firms. Nelson (1959) referred to the problem of externalities due to the public good character of knowledge.
} 
capture these developments, models incorporating endogenous technological change were developed, but the empirical base for the linkage between environmental policy and technical change was weak (Popp, 2002). In the past few years, significant improvements in the description of technological progress in climate policy assessment models have been achieved. The purpose of this paper is threefold: First, we want to sketch the different options for modeling technological change on both a microeconomic and macroeconomic level, where our main focus will lie on large-scale macroeconomic models. Second, we want to give an overview of the different models surrounding climate change and energy economics. How is technological change implemented in the models? How does this affect the results? Which efforts have been made to endogenize the technological progress previously treated as exogenous? And finally we want to give a brief discussion of open research issues. This paper is structured as follows: After this introduction we present different ways to model technological change in climate-energy-economy models: exogenous technical change, which relies heavily on the assumption of autonomous energy efficiency improvements (AEEI); semi-endogenous specifications of backstop technologies; and endogenous specifications of technological change via (price) inducement, investment in research and development $(\mathrm{R} \& \mathrm{D})$, spillover effects resulting from innovations, and finally learning-by doing. ${ }^{5}$ We extend these "classical" modeling approaches to endogenous technical change by a discussion of directed technical change. The mechanisms described play a crucial role in understanding why the exogenous treatment of technological change could be an oversimplification, leading to "black box" results. Finally, we conclude with suggestions for future research efforts, such as more careful incorporation of uncertainties, consideration of potential path-dependence and lock-in situations, and more realistic modeling with respect to heterogeneity of firms and their investment decisions.

\section{Technological Change and Economic Modeling}

\section{A Bottom-Up Modeling}

Modeling the impacts of climate policy on the economy, on the energy system and on the environment basically can be conducted from two perspectives. The first way, called "bottom-up", emphasizes a very detailed description of the technological treatment of the energy system, treating the rest of the economic structure in a rudimentary way. By doing so, models of this type are often partial equilibrium models, focusing on the energy sector and not taking into account potential repercussion effects of climate policy measures on the rest of the economy (Löschel, 2002). They use a large set of energy technologies, e.g. based on information provided by

\footnotetext{
${ }^{5}$ This article extents and updates to work from Löschel (2002). Other sources for surveys on technological change and environmental and energy models are (in alphabetical order) e.g. Clarke et al. (2006, 2008); Gillingham et al. (2008); Grubb et al. (2002); Grübler et al. (2002); Köhler et al. (2006); Pizer and Popp (2008); Popp et al. (2009); Sue Wing (2006) and the special issues of Ecological Economics (Vol. 54, 2005), Energy Economics (Vol. 26, 2004), Resource and Energy Economics (Vol. 25, 2003) and The Energy Journal (2006).
} 
engineers, in order to represent possible substitutions of one energy technology for another at the primary and final energy level, process improvements, or energy savings (incremental technical change). Furthermore, they allow for new technologies to suddenly appear and penetrate the market (snapshot approach) and hence, in part, for radical technical change. These new technologies and their penetration of the market are then based on their costs and performance characteristics. In bottom-up approaches the final energy demand (or emission reduction target) is usually determined outside the model and the model tries to find the least-cost solution to satisfy the given constraints. Exemplary for this type of models are the MARKAL, MESSAGE, and POLES families of models.

\section{B Top-Down Approaches}

The second possible way, called "top-down", emphasizes a detailed description of the economy (e.g. a higher sectoral resolution, production structures, interdependencies) and neglects particularly detailed information on the technological issues of the energy system. ${ }^{6}$ The class of top-down models can be subdivided into three different categories: macroeconometric models, computable general equilibrium (CGE) models and integrated assessment models (IAM). Macroeconometric models are usually based on long-run time-series data and hence have a sound empirical base. They employ econometrically estimated equations without relying on equilibrium assumptions. They are very rich in economic detail and the traditional models follow a neo-Keynesian theoretical approach assuming a demand-driven structure and the possibility of under-utilization of productive capacity. Therefore they are especially suited for short-term and medium-term forecasting (Carraro, 2002). Computable General Equilibrium (CGE) models are a widely used tool in the evaluation of climate policy measures. They are well-understood Arrow-Debreu models that include the interaction of consumers, producers, prices, markets and repercussion effects from various different policies. Most frequently the household preferences and the production side are depicted by constant elasticity of substitution (CES) functions. Their focus lies mainly on a detailed and structural picture of the economy and a large coverage of countries. Models of this type are, e.g., PACE, GTEM, GEME3, MIT-EPPA or DEMETER. Finally, integrated assessment models of climate change take the most comprehensive approach towards the evaluation of climate change policies, by taking into account the impacts of particular policy measures and technological developments on the climate. They incorporate climate-economy or climate-energy submodules and damage functions. Examples of such models are the popular models of the DICE/RICE family, WITCH, MERGE, PAGE and FUND.

\footnotetext{
${ }^{6}$ However, there exist approaches to combine bottom-up with top-down models (a "hybrid approach")
} 


\begin{tabular}{|c|c|c|c|}
\hline TYPE & Focus & Technological Change & Models \\
\hline \multicolumn{4}{|l|}{ Bottom-Up } \\
\hline & Energy System & $\begin{array}{c}\text { Exogenous, Learning-by-Doing } \\
\text { Snapshots }\end{array}$ & $\begin{array}{l}\text { MARKAL, MESSAGE } \\
\text { POLES }\end{array}$ \\
\hline \multicolumn{4}{|l|}{ Top-Down } \\
\hline Macroeconometric & Economy & Exogenous & DGEM \\
\hline CGE & Economy & Learning-by-Doing' & $\begin{array}{l}\text { PACE, GTEM, GEM-E3 } \\
\text { MIT-EPPA, DEMETER }\end{array}$ \\
\hline Integrated Assessment & $\begin{array}{l}\text { Economy, Energy } \\
\text { System, Environment }\end{array}$ & $\begin{array}{c}\text { Backstops, Directed } \\
\text { Technical Change }\end{array}$ & $\begin{array}{l}\text { DICE, WITCH, RICE } \\
\text { ENTICE, PAGE }\end{array}$ \\
\hline
\end{tabular}

Table 1: Model Types and Implementation of Technological Change

\section{Exogenous Technological Change}

The exogenous modeling of technological change is a very common approach in the empirical assessment of long-term climate change policy evaluation. Here, technological change is represented as (exogenous) improvements of energy efficiency. One can interpret technical change in such a framework as being a function solely of the time that passes (Popp et al., 2009). In the case of exogeneity, technological change is independent of policy measures such as a carbon tax or a cap-and-trade scheme for emissions permits. Another modeling strategy of exogenous technical change can be the implementation of a (known but very expensive) "backstop" technology, a notion that was subtly hinted at in Hotelling's seminal paper on resource economics (?), introduced formally by the equally seminal contribution by Dasgupta and Heal (1974) and labeled backstop technology by Nordhaus (Nordhaus, 1973, p. 532). For instance, the technology of harnessing solar energy, fusion power or carbon capture and sequestration (CCS) can be perceived as a backstop technology to oil, coal and natural gas. Both possibilities of modeling exogenous technical change, the autonomous energy efficiency improvement (AEEI) ${ }^{7}$ and the "semi-endogenous" backstop technology approach (Sue Wing, 2006, p. 552) are frequently used.

\section{A Autonomous Energy Efficiency Improvement}

Exogenous growth theory has its roots in the work of Solow (Solow, 1956, 1957). The easiest approach to technical change is to assume that Hicks-Neutral productivity improvements determine the overall progress of the economy. Such an approach

${ }^{7}$ The AEEI parameter is one of three parameters in exogenous modeling of technological change in energy and environment models. The other two are the price elasticity of energy-demand and the income elasticity of demand for energy (Azar and Dowlatabadi, 1999). 
neglects the possibility of technological progress enhancing the energy efficiency of inputs. 8

The concept of Hicks-Neutral technological change which does not alter the shape of the isoquants can be illustrated by relying on standard neoclassic production functions. I do not consider a specific form of a production function here. This general production function here is rather assumed to satisfy the usual conditions of continuity, differentiability, positive and diminishing marginal products, constant returns to scale and the Inada conditions and producing output from a dirty input $\left(D_{(t)}\right)$ and a clean input $\left(C_{(t)}\right)$. $A_{(t)}$ denotes technological progress:

$$
Y_{(t)}=F\left(A_{(t)}, C_{(t)}, D_{(t)}\right)=A_{(t)} F\left(C_{(t)}, D_{(t)}\right)
$$

Many approaches to the economics of climate change have therefore assumed a decoupling of economic growth and energy use via an exogenous AEEI, decoupled from any policy decisions and price developments.

It terms of our neoclassical production function this can be written as:

$$
Y_{(t)}=F\left(A_{(t)}, C_{(t)}, D_{(t)}\right)=F\left(A_{(t)} C_{(t)}, D_{(t)}\right)
$$

or alternatively

$$
Y_{(t)}=F\left(A_{(t)}, C_{(t)}, D_{(t)}\right)=A_{(t)} F\left(C_{(t)}, A_{(t)}^{D} D_{(t)}\right)
$$

where autonomous energy efficiency improvement is characterized as:

$$
\operatorname{AEEI}_{(t)}=\frac{\frac{\partial A_{(t)}}{\partial t}}{A_{(t)}}>0 \quad(\text { for }(2)) \quad \text { and } \quad \operatorname{AEEI}_{(t)}^{D}=\frac{\frac{\partial A_{(t)} D}{\partial t}}{A_{(t)^{D}}}>0 \quad(\text { for }(3))
$$

To ensure that improvements in energy efficiency on the right hand side of equation (4) are occurring in the relatively dirty production the following condition needs to be satisfied:

$$
A_{(t)}^{D}>A_{(t)} \geq 0
$$

In more disaggregated models, such as IAMs or CGE models, the AEEI parameter can be incorporated in a more sophisticated manner (see e.g. Capros and Mantzos (2000); Richels and Blanford (2008) and Jacoby et al. (2006)). In this case, the AEEI depicts both technological progress and structural changes in the economy Richels and Blanford (2008). Jacoby et al. (2006) use different AEEI parameters for different regions in the world in their MIT-EPPA model. Richels and Blanford (2008) investigate the role of technological progress in decarbonizing the U.S. economy. To conduct sensitivity analysis they use three different values for the AEEI: a pessimistic value of 0 , a moderate 0.8 based on historical observations and an opti-

${ }^{8}$ Note, however, that models including exogenous technological change allow for substitution between different inputs on the production side as a response to changes in relative prices (Grubb et al., 2002). 
mistic value of 1 . As it turns out, the impact of different values for the AEEI is quite substantial with no growth for primary energy use until 2050 for 1, a slight increase for 0.8 and a $50 \%$ increase for 0 Richels and Blanford (2008). The advantage of using the AEEI approach is obvious: simplicity, transparency and ease of performing sensitivity analysis (Popp et al., 2009). A major problem of the AEEI is the "black box" character of technological change, which ignores price-inducements and innovation decisions, and makes it difficult to distinguish between technical progress and long-term price effects (Löschel, 2002). Another problem of the AEEI approach is the exclusion of radical technical change by relying on incremental technological progress only (Sue Wing, 2006). Given large technological uncertainties, this is not always a realistic assumption and new technologies can suddenly appear as a shock instead (see, e.g., Löschel and Otto (2009)).

\section{B Backstop Technologies}

A next step forward towards endogenizing technical change is the recourse on "backstop" technologies. These technologies are usually carbon-free energy sources that might be already known but not in commercial usage today. Modeling the supply of a backstop technology is relatively simple, as one need only to determine the marginal cost hurdle $\left(p_{(t)}^{b}<p_{(t)}\right)$ and the date from which on the technology will be available in the future (denoted as $t_{b}$ ). In top-down models it is usual to modify the production function which alters from the old parametrization to the new with the backstop technology. In terms of the neoclassical production from above the implementation of a backstop technology can be incorporated by:

$$
Y_{(t)}=F^{*}\left(C_{(t)}, D_{(t)}, A_{(t)}\right) \quad \text { if } p_{(t)}^{b}<\overline{p_{(t)}^{b}} \text { and } t \geq t_{b}
$$

If the exogenously specified date $t_{b}$ and the cost hurdle $p_{(t)}^{b}<p_{(t)}$ the production function alters to:

$$
Y_{(t)}=F^{*}\left(C_{(t)}, B_{(t)}, A_{(t)}\right) \quad \text { with } B_{(t)} \text { as the "backstop-input" }
$$

However, careful modeling in top-down models is necessary; otherwise the market will be completely dominated by the new technology. But the old energy supply technology and the new backstop technology will certainly coexist for a particular time. A solution to avoid such an unrealistic structural break in the model is a limitation of the penetration rate of the newly available technology and hence treating the "old" outputs and "new" outputs as imperfect substitutes (Popp, 2005). As Sue Wing (2006) proposes it is possible to regulate such an overemphasized penetration of the backstop technology through a fixed factor $Z_{(t)}^{b}$ which replaces the dirty input only gradually and represents e.g. market barriers. Then our production function is:

$$
Y_{(t)}=F^{*}\left(C_{(t)}, Z_{(t)}^{b}, A_{(t)}\right)
$$

Like the AEEI parametrization this approach is partly dissatisfying. Since we are unable to predict the specific details and costs of possible new technology options 
that will be accessible in the far distant future we have to make simplifying assumptions with regard to e.g. the resource demand for the backstop technology, potentially other negative environmental effects of such a technology ${ }^{9}$ and so on. Sue Wing (2006) calls the backstop methodology semi-endogenous because of the fact that it is exogenously specified by the modeler, assuming that it does not need to be developed but that the appearance of the backstop technology is dependent on the (endogenously) determined energy price. Additionally it is often assumed that the cost of the backstop is decreasing with an exogenous rate (Popp et al., 2009) or due to learning-by-doing as e.g. in Manne and Richels (2004), where the authors assume in a high-cost scenario the decline of the costs for the carbon-free backstop technology from 90.0 mills $/ \mathrm{kWh}$ to $60.0 \mathrm{mills} / \mathrm{kWh}$ and in a low-cost scenario to 40.0 mills/kWh. Another study that employs a further endogenization of the backstop technology approach is Popp (2005), where the author calculates the welfare effects of (partly) endogenous backstop technologies. He finds, that, depending of the assumed price of the backstop technology, the welfare gains from restricted emissions policies are in the case of a constant price backstop approach (exogenous) compared to the business as usual (BAU) scenario between $9.1 \%$ for a high backstop price and $111.6 \%$ for a low price and for an endogenous backstop approach (through R\&D in the backstop technology) are between $19.8 \%$ (high price) and $138.9 \%$ (low price) (Popp, 2005, p. 205). However, assumptions with respect to backstop technologies are, more or less, a look into the crystal ball lacking of a sound scientific base by not taking into account e.g. non-linearities of complex economic systems.

\section{Endogenous Technological Change}

A considerable amount of research has been done in the past few years on endogenizing technological change. The efforts to endogenize technological change can be roughly subdivided into four parts: price-induced technological change in the spirit of Hicks (1932), learning-by-doing introduced by Arrow (1962), expenditures and subsidies of research and development, and finally directed technical change, formalized by Acemoglu (2002) and Acemoglu et al. (2012).

\section{A Technological Change in Large-Scale and Aggregated Environmental Models}

\section{Price-Induced Technological Change}

The concept of (price) induced innovations was first introduced by Hicks (1932). Changes in relative factor prices cause firms to introduce technological change in production in order to reduce the input of the factor that has become relatively more expensive. After the oil two crises in 1973 and 1979, energy-saving technological change received a lot of interest from both politics and science. A strand of literature

\footnotetext{
${ }^{9}$ Nuclear power was regarded as a backstop technology for fossil fuel power generation until the accidents at Three Mile Island and the even worse accidents at Chernobyl 1987 and Fukushima in 2011.
} 
emerged dealing with the question whether increasing energy prices also induced technical change to find cleaner production technologies. Kennedy (1964); ? and Ahmad (1966) have formalized the qualitative argument postulated by Hicks and Binswanger. Due to the increasing public awareness of climate change, energysaving technological change again receives a lot of attention. Empirical studies investigating the relationship between energy prices and technological progress are e.g. the seminal contribution by Popp (2002) or, more recently, research by Abadie and Chamorro (2008) on carbon pricing and its effects on technology. In the case of applied economic models of price-induced technical change, rising energy prices induce technical change, which then leads to energy efficiency improvements, most commonly conceptualized through a productivity parameter tied to historic and/or current energy prices or through an earlier diffusion of energy-efficient technologies (Popp et al., 2009). In terms of our production function, the technology parameter $A_{(t)}^{i}$, with $i \in C, D$ reacts to the relative price of the clean $p_{(t)}^{C}$ and dirty $p_{(t)}^{D}$ inputs.

$$
\frac{\frac{\partial A_{(t)^{i}}}{\partial t}}{A_{(t)^{i}}}=\Gamma\left[p_{(t)}^{C}, p_{(t)}^{D}\right]
$$

Several studies mainly employ the price-induced hypothesis. ${ }^{10}$ In ICAM-3 (IAM), Dowlatabadi estimates the welfare costs of different climate policies until 2010. Exogenous technological change (through AEEI) is combined with price-induced technological change (called "price-induced efficiency (PIE)" (Dowlatabadi, 1998, p. 483). This approach replaces the original AEEI as a more realistic assumption with respect to the development of energy efficiency and energy prices. Depending on the model scenario (learning-by-doing was also included in some runs), the differences between exogenous and PIE models are significant. While the purely exogenous treatment of technological improvement leads to a welfare loss of $0.23 \%$, the corresponding loss is $0.14 \%$ when price-induced energy-efficiency improvements are taken into account, although energy use and also emissions are substantially higher in the second model runs. "[B]ut the costs of abatement are on a par [...], simply because purposive technical change makes policy interventions more potent", notes Dowlatabadi (Dowlatabadi, 1998, p. 490). The GTEM (CGE) by Jakeman et al. (2004) investigates four commitment periods until 2027. They compare their reference case (without price-induced technical change and without climate policy measures) to a case with climate policy measures included in the Kyoto Protocol (emissions trading and the Clean Development Mechanism) and no price-inducement as well as a case with policy measures and price-inducement. The authors assume a constant and fixed amount of technical change in each of the 9 modeled regions and over the whole time horizon. For 2010, they find a carbon price of US $\$ 115$ (2002) without price-induced effects and a substantially lower price of US $\$ 88$ with

\footnotetext{
${ }^{10}$ Note, however, that most models use several approaches to technological change. Some rely on a mixture of exogenous and endogenous technological change, some rely on e.g. learning-bydoing and price-induced technological change, and sometimes it is hard to distinguish which type of modeling drives the results (Popp et al., 2009).
} 
price-induced effects, concluding that "incorporating the induced innovations hypothesis results in a stronger bias in technical change toward economizing on the use of inputs that create emissions" (Jakeman et al., 2004, p. 951). However, the inclusion of price-induced technological change, although being identified as one partial explanation for technological change, is only a first step and alternative ways of modeling technological change, as e.g. R\&D or learning-by-doing, have been introduced in climate-energy-economy models. These approaches will be presented in the following subsections.

\section{Directed Technological Change}

In 2002 Acemoglu revived the debate about induced and endogenous technological change with his model of directed technical change in general (Acemoglu, 2002) and in the environmental case in particular (Acemoglu et al., 2012). In his model, the same goods can be produced using either clean or dirty technologies, and firms typically select the more profitable of the two due to profit maximization. As long as the dirty technology enjoys an initial installed-base advantage, innovations will focus on further improvements to the dirty technology. To put it differently: people prefer to work at what they already know and the clean technology may never be used at all unless the government decides to intervene. Governments therefore need to influence not only the allocation of production between clean and dirty activities, but also the allocation of research and development between clean and dirty innovation. This means that there are not one but two major issues that must be dealt with: the standard negative environmental externality generated by polluting production activities as well as the fact that past or current technological advances in dirty technologies make future production and innovation in clean technologies relatively less profitable. Therefore Acemoglu introduced the approach of "directed" technological change. Such a directed technological change perspective introduces a new cost-benefit analysis to policy intervention. The cost of supporting cleaner technologies is that this may slow down growth in the short run, as cleaner technologies are initially less advanced. But supporting cleaner technologies might bring about less dirty growth in the long run (Acemoglu et al., 2012). Studies employing this directed technical change approach are e.g. Otto et al. (2008); Otto and Reilly (2008) and Löschel and Otto (2009). The computable general equilibrium model of the former authors includes technical change in the form of innovation possibility frontiers, which describe investment in knowledge capital in the different sectors and therefore treat knowledge capital as sector specific. Technical change is "directed" to a specific sector if its investment in knowledge capital increases relative to other sectors. They also take into account the positive externality characteristic of research and development, so that the representative producer does not consider these externalities in making investment decisions and thus underinvests in knowledge capital from a social welfare perspective. In Otto et al. (2008), the authors investigate the effects of directed technical change on differentiated climate policies. They calibrate their model on the Dutch economy and run three different climate policy simulations. First, they investigate differentiated CO2 emission constraints. 
Then, they analyze differentiated R \& D subsidies. And finally, they explore the effects of efficient combinations of both. They find that optimally differentiated R \& D subsidies achieve a $10 \%$ reduction in $\mathrm{CO} 2$ emissions and simultaneously improve the welfare of the Dutch economy by about $11 \%$ relative to the reference case. These positive welfare effects until 2025 are even larger in the case of optimally differentiated R\& D subsidies in combination with differentiated CO2 emission constraints (roughly $30 \%$ ). Bye and Jacobsen (2011) use the model of Heggerdal and Jacobsen (2010), which is described in more detail in a later section, to investigate the effect of directed technical change towards carbon capture and storage (CCS) in Norway. The authors find that, given a low carbon tax, reallocating R \& D support to general R \& D improves welfare, while reallocating R \& D support to CCS R \& D reduces welfare. The main reasons are decreasing returns to scale and decreasing returns to knowledge, which together contribute to dampening the positive welfare effects of the CCS-directed subsidy. Some cautious conclusions, which are relevant for the whole debate on directed technical change, have to be drawn: "The difficulty, however, is how to design such technology policy in reality. [...] So, the answer depends in part on perspective and in large part on the confidence one has that public policy can effectively direct R\& D" (Otto et al., 2008, p. 2868).

Learning-by-doing

A third possibility of introducing endogenous technical change is the concept of technology learning. Such learning was first observed by aeronautic engineers in the 1930's. They found that, as the quantity of manufactured units doubles, the number of direct labor hours it takes to produce an individual unit decreases at a uniform rate (Wright, 1936). In economics, technology learning was formalized by Arrow (1962) and its empirical implications are still under investigation (see e.g. Thornton and Thompson (2001) for the case of wartime ships and Thompson (2012) for further discussion.). Introducing a new technology (e.g. CCS) can be very costly at the beginning, but as industries or individuals gain experience by using the new technology, its costs decline. The Boston Consultancy Group (BCG) operationalized Arrow's concept of learning-by-doing by introducing experience or learning curves, which describe technological progress as a function of accumulating experience (e.g. measured by cumulative output) with either production (learning-by-doing in industries) or use (learning-by-doing for consumers). One crucial decision the modeler has to make concerns the functional form and shape of the learning curve for a particular technology. A common approach is to assume that the current unit cost for the production of a good in year $t, c_{(t)}$ is a decreasing function of its cumulative output in previous periods, $Y_{(t)}$. The standard model of learning-by-doing assumes a power rule as a functional form, $c_{(t)}=c(0) y(t)^{-\beta}$, where $\beta$ is the rate of learning (or learning index). With this definition, every doubling of total installed capacity reduces specific unit costs by a factor of $2^{-\beta}$. This factor is also called progress ratio and describes the speed of learning. The complementary learning rate (Learning rate $=1$ - progress ratio) gives the percentage reduction in the specific capital cost of newly installed capacity for every doubling of cumulative capacity (Löschel, 2002). 
Technology learning can be segmented in different phases. While high learning rates can be observed in the research, development and deployment phase, learning rates become lower in the commercialization (diffusion) phase. When the situation of market saturation is reached, the learning rate may even drop to zero. We refer the interested reader to the surveys dealing with learning/experience curves in the energy sector carried out by Neij (2008) and Ferioli et al. (2009). As mentioned above, bottom-up energy system models strongly emphasize the energy sector and the emissions occurring from energy production and consumption. Such detailed modeling of the energy sector allows taking into account specific characteristics of different energy technologies such as learning or experience curves. A variety of bottom-up models have integrated technological change via learning-by-doing. Examples are the TIMES model (Loulou et al., 2005) and the closely related MARKAL and MESSAGE models (former: Loulou et al. (2004); latter: Messner and Schrattenholzer (2000)). All models are very similar in their structure and their treatment of technological change. All models include learning-by-doing for several technologies. They also allow "clustered learning", where several technologies use the same key technology (or component), which is in turn subject to learning itself, so that these models can take into account technology spillover effects. And finally, they also allow incorporation of technology learning for technologies that are truly global(e.g. turbines or innovations in the steel industry) in the sense that the same (or close to the same) technology rather rapidly becomes commercially available worldwide. In this way, global experience benefits worldwide users of the technology and learning creates global spillovers (Loulou et al., 2004, 2005). Other examples of bottom-up models using the learning-by-doing mechanism are the PRIMES model (Capros and Mantzis, 2000) and the POLES model (Kouvaritakis et al., 2000). Capros and Mantzos (2000), for example, evaluate the Kyoto Protocol under three different scenarios of learning. The first implies no learning: the authors assume a lack of perception of emission reduction targets and therefore those targets do not affect decisions on new equipment. Then a scenario of normal learning is adopted. And finally, a fast learning scenario is considered, where consumers are assumed to fully understand the opportunities offered by new technologies and are willing to assume the corresponding opportunity costs without taking into consideration issues related to technology maturity and reliability (Capros and Mantzos, 2000). The authors compare the costs of meeting the Kyoto targets and find that in the fast learning scenario, these costs are substantially lower than in the case without learning, with approx. Euro 20 billion and a carbon price of Euro 190/t versus approx. Euro 7 billion and a carbon price of Euro 117/t for 1990, respectively (Capros and Mantzos, 2000). A study within the framework of computable general equilibrium modeling that employs the learning-by-doing mechanism has been conducted by Gerlagh and van der Zwaan (2003). The authors use the bottom-up CGE model DEMETER, which has a detailed economic structure as well as energy-demand structure. They investigate the effect of a 2-degree climate policy until 2100 and compare their results which incorporate exogenous technical change (they include an AEEI parameter of $1.0 \%$ p.a.) to those with an endogenous learning-by-doing approach "assuming [a] con- 
stant learning rate, which is the rate at which production costs decline for each doubling of cumulative experience" (Gerlagh and van der Zwaan, 2003, p. 43). They find that "including endogenous innovation in a macroeconomic model implies earlier emission reductions to meet carbon concentration constraints than in a model with exogenous technological progress. We find that the effect is stronger than suggested so far in the literature" (Gerlagh and van der Zwaan, 2003, p. 54). To briefly outline the magnitude, the costs of compliance with the 2-degree target are a 0.19 $\%$ welfare loss in the case of the exogenous specification and a $0.06 \%$ loss in the case of endogenous technological change (being roughly one third of the first figure). Studies relying on integrated assessment models have been conducted e.g. by Manne and Richels (2004) with their MERGE (IAM) or Alberth and Hope (2007) with PAGE2002 (IAM). Manne and Richels (2004) employ the MERGE integrated assessment model to evaluate the implications of learning-by-doing on climate policy until 2100. The authors include, beside exogenous technological progress in more conventional technologies (e.g. pulverized coal without CO2 recovery), the endogenous technology learning aspect in various ways. First, they incorporate learningby-doing for the case of a carbon-free backstop technology. Their approach allows learning-by-doing through cumulative experience with this technology. The authors assume that learning costs decline by $20 \%$ for every doubling of cumulative experience (Manne and Richels, 2004, p. 606), that learning-by-doing is based on global diffusion and that the growth of experience in one region will hence reduce the costs of a technology in all regions (spillover effects). In order to conduct sensitivity analysis, the authors also assume two different cost scenarios for the backstop technology (low-cost and high-cost). Furthermore, the authors also allow for learning effects in other, non-electric sectors. The capital structure in the MERGE model can be described as "putty-clay", since "introduction and decline constraints are placed on new technologies. We assume that the production from new technologies in each region is constrained to $1 \%$ of the total production in the year in which it is initially introduced and can increase by a factor of three for each decade thereafter. The decline rate is limited to $2 \%$ per year for new technologies, but there is no decline rate limit for existing technologies" (Manne and Richels, 2004, p. 608). This prevents situations in which a carbon-free backstop technology penetrates the market in a very rapid and seemingly unrealistic way. The results from the empirical exercise of Manne and Richels (2004) show mixed evidence for the effects of learningby-doing. When the authors include a high price for the backstop technology, the effects on global emissions are close to the effect with no learning-by-doing. But the learning-by-doing mechanism can at least help to substantially lower the costs of climate policy (by approx. $42 \%$, or from about US $\$ 4$ trillion to about US $\$ 2$ trillion). If the low-cost backstop price is assumed, greenhouse gas emissions will increase until 2070 and then drop to $20 \%$ of the level of the no learning-by-doing (high-cost) scenario. The costs of climate policy are then cut back by about $72 \%$ to approx. US \$ 1 Trillion ${ }^{11}$ Alberth and Hope (2007) use the PAGE2002 model (also

\footnotetext{
${ }^{11}$ These numbers are for a $550 \mathrm{ppm}$ stabilization scenario and assume a discount rate of $5 \%$ (Manne and Richels, 2004).
} 
used by Sir Nicholas Stern for his Report on the Economics of Climate Change) to evaluate climate policy under a $450 \mathrm{ppm}, 500 \mathrm{ppm}$ and $550 \mathrm{ppm}$ scenario and its effects on global emissions until the year 2200. The authors consider two different AEEI parameters $(0.1 \%$ p.a. in a pessimistic case and $0.25 \%$ p.a. in a more optimistic case). Furthermore, they include a learning parameter coefficient of 0.04 to 0.36 , which is tantamount to a learning rate of 5-25\%. Their approach towards sensitivity analysis is to incorporate two different initial experience stocks for the backstop technology (measured as cumulative historical CO2 abatement realized by the carbon-free source). The authors find that "the three stabilisation scenarios modelled remain very similar to those of the standard PAGE2002 model. [...] The similarity of the two models, however, is heavily dependent on the coefficients used, and the sensitivity analysis further demonstrates that the learning coefficient has a strong impact on the calculation of total abatement costs" (Alberth and Hope, 2007, p. 1804). However, there exist several problems with the learning-by-doing approach. Learning-by-doing is often regarded as ad-hoc, lacking transparency. This can be the case if there are several different technologies in the model (e.g. in bottom-up models), whereby different learning rates and spillover effects are assumed. Another problem can be the critical assumption "shared by virtually all LBD studies that carbon-free technologies experience the most rapid learning and cost reductions, while their conventional counterparts enjoy little or no improvement. ... Not only is this outcome quite speculative given our limited understanding of the association between unit cost reductions and the diffusion of new technologies, it is virtually a pre-determined outcome of the simulation" (Sue Wing, 2006, p. 555).

Research 85 Development

Technological change can be interpreted as an economic activity in which agents maximize their profits. By investing in R \& D firms, they try to decrease production costs in the long run and thus establish market advantages. Following this train of thought, we can consider investment in R\&D as a decision about the stock of knowledge. Sue Wing (2006), for instance, presents an approach where knowledge is treated as capital, the accumulation of which is determined by its level of investment and its depreciation rate. The key problem of this view is the imperfection of knowledge markets. In particular, investment in R\& D creates spillovers, which drive a wedge between private and social returns to R \& D (Popp et al., 2009). Spillovers from R \& D, or positive technological externalities, are an element of technological change strongly connected with investment in R\&D. ${ }^{12}$ They arise when information obtained by the innovative activities of one economic agent becomes public,

\footnotetext{
${ }^{12}$ Clarke et al. (2006) present several classifications of spillover effects. First, we can categorize direct and indirect spillovers. The former result from technological advances in one industry which do not require any additional efforts from the receiving industry. The latter need own exploitation activities by the recipient. Second, we can distinguish international (between countries), interindustry (between industries) and intra-industry (within one industry) spillover effects. In addition, Clarke et al. (2006) classify rent spillovers and knowledge spillovers. Rent spillovers occur when economic benefits are transferred. Analogously, knowledge spillovers arise when knowledge is transmitted.
} 
so that other agents, not involved in the innovation process, profit by using this information or even copying the whole product. Since society in general benefits from spillover effects, it is now clear why social rates of return to R \& D investments are higher than the private rates. Nordhaus (2002) finds evidence for social returns of $30 \%$ to $70 \%$ p.a., while private returns on capital range between $6 \%$ and $15 \%$ p.a. in the United States. As Löschel (2002) finds, recent models treat knowledge as a non-rival and not fully appropriable good. Research results cannot be completely predicted and R \& D efforts frequently involve high costs. Both facts enhance the degree of uncertainty. Clarke et al. (2006) call attention to the broad range of activities inherent in $\mathrm{R} \& \mathrm{D}$ investments. Regarding the focus of research they distinguish basic research, i.e. research focusing on fundamental scientific understanding, from applied research, which attempts to improve specific technologies. Although the former basically deals with theoretical background work, it is not free from application-oriented goals. Another distinction can be made with respect to the institutions funding $\mathrm{R} \& \mathrm{D}$, so that we can distinguish public from corporate research investment. As mentioned above, private and social rates of return usually differ greatly. Firms "underinvest" in R\&D because they ignore the social returns. It is for this reason that governments often finance research efforts (Pizer and Popp, 2008). To put it otherwise, $\mathrm{R} \& \mathrm{D}$ needs to be subsidized at a rate equal to the marginal external benefit from knowledge spillovers. In this circumstance, the private and social costs of R \& D will become the same (Goulder and Schneider, 1999). In climate policy models, this issue becomes relevant because the public sector might be motivated to introduce certain policies whereas the private sector responds to those policies (Clarke et al., 2006). To put it otherwise, "public R \& D motivated by the climate challenge is climate policy, whereas private R \& D responds to climate policy (e.g., prices on emissions, deployment policies, R\& D subsidies)" (Clarke et al., 2008, p. 412). Furthermore, R \& D subsidies by the government sector can help advance commercialization of innovative technologies combining basic and applied research, a point taken up by Pizer and Popp (2008). An important modeling issue can also be the fact that money supplied for R \& D is limited (as is the number of engineers and researchers) and increasing spending on one particular set of technologies (such as decarbonization) can reduce or "crowd out" R \& D spending on other sets of technologies such as medicine (Popp, 2004). Investment in R \& D is typically modeled via a variable representing $\mathrm{R} \& \mathrm{D}$ or knowledge, respectively. In non-environmental models, the emphasis is usually on productivity gains through research. In climate models, additional emphasis is put on decreasing greenhouse gas emissions and reducing abatement costs. The pioneering contribution incorporating R \& D efforts by Goulder and Schneider (1999) was based on a CGE model. They emphasize the effects of spillover effects and divide the knowledge stock into non-excludable knowledge (creating spillovers) and appropriable knowledge. They also include a scaling factor to determine the effect of spillovers on output. The authors find "that the presence of endogenous technological change in their model leads to lower costs of achieving a given abatement target, but higher gross costs of a given carbon tax" (Popp et al., 2009). Sue Wing (2003) extends the work of 
Goulder and Schneider (1999) by distinguishing between several factors that may influence the innovation process, in order to gain insight into the general equilibrium effects of these innovations. He distinguishes between "dirty" and "clean" goods and finds that a carbon tax reduces aggregate R \& D and slows down the rate of technological change and output growth (Popp et al., 2009). More recently, Heggerdal and Jacobsen (2010), using a computable general equilibrium model calibrated on the Norwegian economy, focused on how the timing of innovation policies affects carbon emissions until 2070. Their model contains two R \& D industries. Growth takes place through dynamic spillovers from the accumulated knowledge stemming from R\& D production, though with decreasing returns. A feature of their model is the production structure of $\mathrm{R} \& \mathrm{D}$, which creates new patents. The patent production takes place in two industries, one directed toward general technology and the other toward environmental technology. The authors draw two conclusions. First, the welfare gain from subsidizing environmental R\&D increases with the costs of emissions. This is due to the fact that the carbon tax does not induce a sufficiently large increase in private investment in environmental $\mathrm{R} \& \mathrm{D}$, because of externalities in the innovation process. Second and more interesting, the largest welfare gain comes from a falling time profile of subsidy rates for environmental R \& D, rather than from a constant or increasing profile, when the economy faces increased emissions costs. "This means that when faced with a future price on carbon, it is a better policy to take R\&D action now than to distribute policy incentives evenly across time. The reason for this is that the innovation externalities are larger in early periods" (Heggerdal and Jacobsen, 2010, p. 936). Incorporating R \& D in integrated assessment models can also be done in very different ways. Nordhaus (2002) specifies R \& D expenditures in his modified DICE model (R \& DICE), creating an aggregate knowledge stock that has a negative effect on emission intensity (the emission-output ratio). He rudimentarily accounts for spillovers by assuming that the social and private returns on R\&D diverge. Nordhaus (2002) adds R\&D to his original DICE model by including an innovation possibility frontier (IPF) in the spirit of Kennedy (1964). His IPF relates R \& D inputs to the carbon-energy sector. He compares his results to the earlier exogenous DICE attempts (Nordhaus, 1994) and finds that induced innovation is probably less powerful in emissions reductions compared to substitution. One explanation for this result could be that Nordhaus implicitly assumes that the economy is currently on an optimal path and that any regulatory interference by the government must inevitably push the economy away from that path (Ayres and Warr , 2009). Buonanno et al. (2003) use the regionalized version of DICE (RICE) and extend it for endogenous technological change (ETC-RICE). Similar to e.g. Nordhaus (2002), they also model emission intensity as a function of a knowledge stock that depends on R \& D investment and depreciates at an exogenous rate. Additionally, the authors account for knowledge spillover effects. In their empirical exercise, they evaluate climate policy under the Kyoto Protocol until 2100 and compare the results with exogenous technological change to the endogenous treatment. In general, the costs of domestic action are lower when environmental technical change is endogenous, and they find a much larger 
role of induced innovation. However, their result is mainly driven by the fact that "there is no potential for climate-friendly R \& D to compete with or crowd out other R\& D" (Popp et al., 2009). Popp (2005) investigates such crowding out with his ENTICE model, also based on Nordhaus' DICE, by conducting three experiments. He simulates a scenario without crowding-out effects, which results in tremendous gains from induced innovation of $45 \%$ compared to the base case. Then he studies the case where $50 \%$ of other R \& D is crowded out by new energy R \& D, resulting in a $9 \%$ welfare increase. And finally, he assumes that $100 \%$ of other R\&D is crowded out, which in turn reduces the welfare gains of $\mathrm{R} \& \mathrm{D}$ policies to $2 \%$, hence emphasizing the importance of potential crowding-out effects. Bosetti et al. (2009); Bosetti and Tavoni (2009) and Bosetti et al. (2011) use the WITCH model to explore the effects of different innovation policies on carbon emissions until 2100. In Bosetti et al. (2011) the authors investigate three different innovation policies: R \& D in energy efficiency; R \& D in wind, solar, and carbon capture and storage; and R \& D in breakthrough (or backstop) technologies. An additional feature of their analysis is the consideration of international cooperation in $\mathrm{R} \& \mathrm{D}$. The authors show that such cooperation could be accompanied by large additional benefits $(+10 \%$ to $+30 \%$, depending on the stringency of climate policy). Their conclusion about innovation policies is less optimistic than in other studies, stating that R \& D policies cannot be a substitution for pricing carbon (Bosetti et al., 2011).

\section{Conclusion}

This chapter has summarized alternative approaches towards modeling technological change in numerical models of climate change and the economy, and highlighted the importance of understanding the process of technological change. Although many problems associated with modeling technological change as exogenous have been resolved, numerous questions still remain unanswered. As technological change is an uncertain phenomenon, these uncertainties have to be incorporated in large-scale models more carefully. This holds particularly true for major innovations. First attempts to tackle this problem are the contributions by Löschel and Otto (2009), Baker et al. (2008b), and Bosetti et al. (2009); Bosetti and Tavoni (2009). The latter authors analyze optimal responses to uncertainty in terms of investments in R \& D and its implications for climate policy costs by modeling innovation as a backstop technology characterized by either a deterministic or an uncertain process. They find that uncertainty leads to higher optimal levels of R \& D investment (Bosetti and Tavoni, 2009). Another important dimension of technical change that has to be taken into account is the potential for path-dependency, inertias and lock-in situations. Path-dependency, a concept coined by Arthur (1989, 1994) and also called "state dependency" (Acemoglu, 2002, p. 791), captures the notion that further technological change is dependent on prior technical change and hence that the process of technical change is inflexible in that once a dominant technology emerges, it might be difficult to switch to competing technolo-

gies. Environment-energy-economy models can account for such effects by careful 
inclusion of learning-by-doing, time lags, assumptions about the diffusion rates of innovations and directed (or biased) technological change. Studies of these effects have been conducted by Otto et al. (2008); Otto and Reilly (2008) and others. A further important aspect of the innovation process not appropriately accounted for is the heterogeneity of firms, as different firms respond differently to environmental policies (Löschel, 2002).

\section{REFERENCES}

Abadie, L., Chamorro, J. (2008): European $\mathrm{CO}_{2}$ prices and carbon capture investments, in: Energy Economics, Vol. 30, No. 4, pp. 2992-3015.

ACEmoglu, D. (2002): Directed Technical Change, in: The Review of Economic Studies, Vol. 69, No. 4, pp. 781-809.

Acemoglu, D., Aghion, P., Bursztyn, L., Hemous, D. (2012): The Environment and Directed Technical Change, in: The American Economic Review, Vol. 102, No. 1, pp. pp. 131-166.

Ackerman, F., DeCanio, S.J., Howarth, R.B., Sheeran, K. (2009): Limitations of integrated assessment models of climate change, in: Climatic Change, Vol. 95, pp. 297-315.

Ahmad, S. (1966): On the Theory of Induced Invention, in: The Economic Journal, Vol. 76, pp. 344-357.

Alberth S., Hope, C. (2007): Climate modeling with endogenous technical change: Stochastic learning and optimal greenhouse gas abatement in the PAGE2002 model, in: Energy Policy, Vol. 35, pp. 1795-1807.

Aldy, J., Krupnick, A., Newell, R., Parry, I. and Pizer, W. (2010): Designing Climate Mitigation Policy, in: Journal of Economic Literature, Vol. 48, pp. 903-934.

Allen, R.C. (2009): The Industrial Revolution in Miniature: The Spinning Jenny in Britain, France, and India, in: The Journal of Economic History, Vol. 69, pp. 901-927.

Arrow, K. (1962): The Economic Implications of Learning-by-doing, in: The Review of Economic Studies, Vol. 29, pp. 155-173.

Atkeson, A. and Kehoe, P.J. (1999): Models of Energy Use: Putty-Putty versus Putty-Clay, in: The American Economic Review, Vol. 89, pp. 1028-1043.

Ayres, R.U., WARR, B. (2009): The Economic Growth Engine, Edward Elgar Publishing Limited, Cheltenham, UK. 
Azar, C., Dowlatabadi, H. (1999): A Review of Technical Change in Assessment of Climate Policy, in: Annual Review of Energy and the Environment, Vol. 24, pp. 513-544.

Azar, C. and Lindgren, K. (2003): Catastrophic Events and Stochastic Costbenefit Analysis of Climate, in: Climatic Change, Vol. 56, pp. 245-255.

Baker, E., Clarke, L., Shittu, E. (2008a): Technical Change and the Marginal Cost of Abatement, in: Energy Economics, Vol. 30, No. 6, pp. 2799-2816.

Baker, E., Clarke, L., Shittu, E. (2008b): Uncertainty and endogenous technical change in climate policy models, in: Energy Economics, Vol. 30, No. 6, pp. 2817-2828.

Balezentisa, A., Balezentisa, T., Streimikienec, D. (2011): The energy intensity in Lithuania during 1995-2009: A LMDI approach, in: Energy Policy, Vol. 39, pp. 7322-7334.

Balistreri, E.J., McDaniel, C.A., and Wong, E.V. (2003): An estimation of US industry-level capital-labor substitution elasticities: Support for CobbDouglas, in: The North American Journal of Economics and Finance, Vol. 14, pp. 343-356.

infinite utility streams, in: Social Choice and Welfare, Vol. 30, pp. 1-12.

Binswanger, H.P., RutTan, V.W. (1978): Induced Innovation: Technology, Institutions and Development, John Hopkins University Press, Baltimore, MD.

BJurström, A. and M. Polk (2011): Climate change and interdisciplinarity: a co-citation analysis of IPCC Third Assessment Report, in: Scientometrics, Vol. 87, pp. 525-550.

Böhringer, C., Rutherford, T. (2008): Combining bottom-up and top-down, in: Energy Economics, Vol. 30, pp. 574-596.

Böhringer, C., Rutherford, T., Tol, R. (2009): The EU 20/20/2020 targets: An overview of the EMF22 assessment, in: Energy Economics, Vol. 31, pp. 268-273.

Bosetti, V., Carraro, C., Massetti, E., Sgobbi, A., Tavoni, M. (2009): Optimal energy investment and R \& D strategies to stabilize atmospheric greenhouse gas concentrations, in: Resource and Energy Economics, Vol. 31, No. 2, pp. 123-137.

Bosetti, V., Tavoni, M. (2009): Uncertain R \& D, backstop technology and GHGs stabilization, in: Energy Economics, Vol. 31, pp. 18-26.

Bosetti, V., Carraro, C., Duval, R., Tavoni, M. (2011): What should we expect from innovation? A model-based assessment of the environmental and 
mitigation cost implications of climate-related R \& D, in: Energy Economics, forthcoming.

Browning, M., Hansen, L.P., and Heckman, J. J. (1999): Micro data and general equilibrium models, in: Handbook of Macroeconomics, Vol. 1, Part A, Chapter 8, pp. 543-633.

Buchholz, W. and Schymura, M. (2012): Expected Utility Theory and the Tyranny of Catastrophic Risks, in: Ecological Economics, Vol. 77, pp. 234-239.

Buonanno, P., Carraro, C., Galeotti, M. (2003): Endogenous induced technical change and the costs of Kyoto, in: Resource and Energy Economics, Vol. 25, No.1, pp. 11-34.

Bye, B., JACOBsen, K. (2011): Restricted carbon emissions and directed R \& D support; an applied general equilibrium analysis, in: Energy Economics, Vol. 33, No. 3, pp. 543-555.

Capros, P., Mantzos, L. (2000): Endogenous learning in European post-Kyoto scenarios: results from applying the market equilibrium model PRIMES, in: International Journal of Global Energy Issues, Vol. 14, pp. 249-261.

Carraro, C. (2002): Climate Change Policy: Models, Controversies and Strategies, in: T. Tietenberg, H.Folmer, eds., The International Yearbook of Environmental and Resource Economics 2002/2003, Edward Elgar Publishing Ltd.

Carraro, C., Massetti, E., Nicita, L. (2009): How Does Climate Policy Affect Technical Change? An Analysis of the Direction and Pace of Technical Progress in a Climate-Economy Model, in: Energy Economics, Vol. 30, pp. 7-37.

Chakravarty, S. (1969) : Capital and Development Planning, MIT Press, Cambridge, MA.

Clarke, L.E., Weyant, J., Birky, A. (2006): On the Sources of Technological Advance: Assessing the Evidence, in: Energy Economics, Vol. 28, pp. 579-595.

Clarke, L.E., Weyant, J., Edmonds, J. (2008): On the sources of technological change: What do the models assume?, in: Energy Economics, Vol. 30, pp. 409-424.

Dasgupta, P.S., Heal, G.M. (1974): The optimal depletion of exhaustible resources, in: Review of Economic Studies, Vol. 41, pp. 3-28.

DAsGuPta, P. (2008): Discounting climate change, in: Journal of Risk and Uncertainty, Vol. 37, pp. 141-169.

Dasgupta, P., And Heal, G. (1979): Economic Theory and Exhaustible Resources, Cambridge University Press, Cambridge, UK. 
Dawkins, C., Srinivasan, T.N., Whalley, J., and Heckman, J.J. (2001): Calibration, in: Handbook of Econometrics, Vol. 5, Chapter 58, pp. 3653-3703.

Devarajan, S. and Robinson, S. (2002): The influence of computable general equilibrium models on policy, in: TMD Discussion Paper.

DowlatabAdI, H. (1998): Sensitivity of climate change mitigation estimates to assumptions about technical change, in: Energy Economics, Vol. 20, pp. 473-493.

Edenhofer, O., BAuer, N., Kriegler, E. (2005): The impact of technological change on climate protection and welfare: Insights from the model MIND, in: Ecological Economics, Vol. 54, pp. 277-292.

Fankhauser, S. (1994): The Social Costs of Greenhouse Gas Emissions: An Expected Value Approach, in: Energy Journal, Vol. 15, pp. 157-184.

Ferioli, F., Schoots, K., van der ZwaAn, B.C. (2009): Use and limitations of learning curves for energy technology policy: A component-learning hypothesis, in: Energy Policy, Vol.38, pp. 2525-2535.

Fuss, M. (1977): The Structure of Technology Over Time: A Model for Testing the "Putty-Clay" Hypothesis, in: Econometrica, Vol. 45, pp. 1797-1821.

Gerlagh, R., vaN DeR ZwAAN, R. (2003): Gross world product and consumption in a global warming model with endogenous technological change, in: Resource and Energy Economics, Vol., Vol. 25, pp. 35-57.

Gerlagh, R., vaN DER ZwAAN, R. (2006): Options and instruments for a deep cut in CO2 emissions: Carbon dioxide capture or renewables, taxes or subsidies?, in: Energy Journal, Vol. 27, pp. 25-48.

Gerlagh, R. (2008): A climate-change policy induced shift from innovations in carbon-energy production to carbon-energy savings, in: Energy Econmics, Vol. 30, pp. 425-448.

Gillingham, K., Newell, R., Pizer, W. (2008): Modeling endogenous technological change for climate policy analysis, in: Energy Economics, Vol. 30, pp. 2734-2753.

Goulder, L.H., Schneider, S. (1999): Induced technological change and the attractiveness of CO2 abatement policies, in: Resource and Energy Economis, Vol. 21, pp. 211-253.

Goulder, L.H., Mathai, K. (2000): Optimal CO2 abatement in the presence of induced technological change, in: Journal of Environmental Economics and Management, Vol. 39, pp. 1-38.

Grimaud, A., Rouge, L. (2008): Environment, Directed Technical Change and Economic Policy, in: Resource and Energy Economics, Vol. 41, pp. 439-463. 
GrubB, M., Köhler, J., Anderson, D. (2002): Induced technical change in energy and environmental modeling, in: Annual Review of Energy and the Environment, Vol. 27, pp. 271-308.

Grübler, A., Köhler, J., Anderson, D. (2002): Technological Change and the Environment, Resources for the Future Press, Washington, DC.

Heggerdal, T.-R., Jacobsen, K. (2010): Timing of innovation policies when carbon emissions are restricted: An applied general equilibrium analysis, in : Resource and Energy Economics, Vol. 33, pp. 913-937.

Held, H., Kriegler, E., Lessmann, K., Edenhofer, O. (2009): Efficient climate policies under technology and climate uncertainty, in: Energy Economics, Vol. 31, pp. 50-61.

Hertel, T., Hummels, D., Ivanic, M., and Keeney, R. (2007): How confident can we be of CGE-based assessments of Free Trade Agreements?, in: Economic Modelling, Vol. 24, pp. 611-635.

Hicks, J. (1932): The Theory of Wages, Macmillan, London, UK.

Jacoby, H.D., Reilly, J.M., McFarland, J.R., and Paltsev, S. (2006): Technology and technical change in the MIT EPPA model, in: Energy Economics, Vol. 28, pp. 610-631.

Jakeman, G., Hanslow, K., Hinchy, M., Fisher, B., Woffenden, K. (2004): Induced innovations and climate change policy, in: Energy Economics, Vol. 26, No. 6, pp. 937-960.

KenNeDy, C. (1964): Induced Bias in Innovation and the Theory of Distribution, in: The Economic Journal, Vol.74, pp. 541-547.

Köhler, J., Grubb, M., Popp, D., Edenhofer, O. (2006): The transition to endogenous technical change in climate-energy models: A technical overview to the innovation modeling comparison project, in: Energy Journal, Special Issue, Endogenous Technological Change and the Economics of Atmospheric Stabilization, pp. 17-55.

Kolstad, C. D. (2000): Energy and Depletable Resources: Economics and Policy, 1973-1998, in: Journal of Environmental Economics and Management, Vol. 39, pp. 282-305.

Kouvaritakis, N., Soria, A., Isoard, S., Thonet, C. (2000): Endogenous Learning in World post-Kyoto Scenarios: Application of the POLES Model under Adaptive Expectations, in: International Journal of Global Energy Issues, Vol. 14, pp. 222-248.

Loulou, R., Goldstein, G., Noble, K. (2004): Documentation for the MARKAL Family of Models, http://www.etsap.org/tools.htm 
Loulou, R., Remne, U., Kanudia, A., Lehtila, A., Goldstein, G. (2005): Documentation for the TIMES Model: Part I, http://www.etsap.org/tools.htm

LöscheL, A. (2002): Technological Change in Economic Models of Environmental Policy: A Survey, in: Ecological Economics, Vol. 43, pp. 105-126.

Löschel, A., Oтto, V. (2009): Technological uncertainty and cost effectiveness of $\mathrm{CO}_{2}$ emission reduction, in: Energy Economics, Vol. 31, pp. S4-S17.

MacCracken, C., Edmonds, J., Son, K., Sands, R. (1999): The Economics of the Kyoto Protocol, in: Energy Journal, Special Issue., pp. 25-72.

MAdDison, D. (1995): A cost-benefit analysis of slowing climate change, in: Energy Journal, Vol. 23, pp. 337-346.

Manne, A., Richels, R. (1992): Buying Greenhouse Insurance: The Economic Costs of $\mathrm{CO}_{2}$ Emission Limits, MIT Press, Cambridge, USA.

Manne, A., Richels, R. (2004): The impact of learning-by-doing on the timing and costs of CO2 abatement, in: Energy Economics, Vol. 26, pp. 603-619.

Mansur, A.H., and Whalley, J. (1984): Numerical Specification of Applied General Equilibrium Models: Estimation, Calibration and Data, in: Applied General Equilibrium Analysis.

MCKITRICK, R.R. (1998): The econometric critique of computable general equilibrium modeling: the role of functional forms, in: Economic Modelling, Vol. 15, pp. 543-573.

Messner, S., Schrattenholzer, L. (2000): MESSAGE-MACRO: linking an energy supply model with a macroeconomic module and solving it iteratively, in: Energy, Vol. 25, pp. 267-282.

Michetti, M., and RosA, R. (2012): Afforestation and timber management compliance strategies in climate policy. A computable general equilibrium analysis, in: Ecological Economic, Vol. 77, pp. 139-148.

NEIJ, L. (2008): Cost development of future technologies for power generation - A study based on experience curves and complementary bottom-up assessments, in: Energy Policy, Vol. 36, pp. 2200-2211.

Nelson, R.R. (1959): The Simple Economics of Basic Scientific Research, in: The Journal of Political Economy, Vol. 67, pp. 297-306.

Nordhaus, W. (1973): The allocation of energy resources, in: Brookings Papers on Economic Activity, Vol. 3, pp. 529-570.

Nordhaus, W. (1991): To Slow or not to Slow: The Economics of the Greenhouse Effect, in: The Economic Journal, Vol. 101, pp. 920-937. 
Nordhaus, W. (1994): Managing the Global Commons: The Economics of Climate Change, MIT Press, Cambridge, USA.

Nordhaus, W. (2002): Modeling induced innovation in climate change policy. In: A. Grubler, N. Nakicenovic and W. Nordhaus, eds., Technological Change and the Environment. Resources for the Future Press, Washington, DC.

Nordhaus, W. (2007): A review of the Stern Review on the economics of climate change, in: Journal of Economic Literature, Vol. 45, pp. 686-702.

Nordhaus, W. (2008): A Question of Balance, Yale Universtiy Press, New Haven, USA, 2008.

Nordhaus, W. (2011): The Economics of Tail Events with an Application to Climate Change, in: Review of Environmental Economics and Policy, Vol. 5, pp. 240-257.

Nordhaus, W., and Boyer, J. (2000): Warming the World - Economic Models of Global Warming, MIT Press Cambridge, MA, 1994.

Otto, V., Löschel, A., Reilly, J. (2008): Directed technical change and differentiation of climate policy, in: Energy Economics, Vol. 30, No. 6, pp. 2855-2878.

Oтto, V., Reilly, J. (2008): Directed technical change and the adoption of $\mathrm{CO}_{2}$ abatement technology: The case of $\mathrm{CO}_{2}$ capture and storage, in: Energy Economics, Vol. 30, pp. 2879-2898.

Pizer, W., Popp, D. (2008): Endogenizing technological change: Matching empirical evidence to modeling needs, in: Energy Economics, Vol. 30, No. 6, pp. $2754-2770$

Popp, D. (2002): Induced Innovation and Energy Prices. in: The American Economic Review, Vol. 92, pp. 160-180.

PopP, D. (2004): ENTICE: Endogenous technological change in the DICE model of global warming. Journal of Environmental Economics and Management 48, 742-768.

Popp, D. (2005): ENTICE-BR: The effects of backstop technology R\&D on climate policy models, in: Energy Economics, Vol., 28, pp. 188-222

Popp, D., Newell, R.G., Jaffe, A.B. (2009): Energy, the Environment, and Technological Change, in: NBER Working Paper, No. 14832

Richels, R.G., Blanford, G.J. (2008): The value of technological advance in decarbonizing the U.S. economy, in: Energy Economics, Vol 30, pp. 2930-2946.

Robinson, L., and Hammitt, J. (2011): Behavioral Economics and the Conduct of Benefit-Cost Analysis: Towards Principles and Standards, in: Journal of Benefit-Cost Analysis, Vol. 2, Article 5. 
SAlter, W.E.G. (1966): Productivity and Technical Change, $2^{\text {nd }}$ edition $\left(1^{\text {st }}\right.$ edition 1960), Cambridge University Press, Cambridge, UK.

SANDmo, A. (2011): Economics Evolving: A History of Economic Thought, Princeton University Press, Princeton, NJ, USA.

SJöström, M., and Östblom G. (2010): Decoupling waste generation from economic growth: A CGE analysis of the Swedish case, in: Ecological Economics, Vol. 69, pp. 1545-1552.

Smith, J.B., Schneider S.H., Oppenheimer M., Yohe, G.W., Hare W., Mastrandrea M.D., Patwardhan A., Burton I., Corfee-Morlot J., Magadza, C.H.D., Füssel H.M., Pittock, A.B., Rahman A., Suarez A., and YPERSELE J.-P. (2009), Assessing dangerous climate change through an update of the Intergovernmental Panel on Climate Change (IPCC) "reasons for concern", in: Proceedings of the National Academy of Sciences, Vol. 106, pp. 4133 - 4137.

Smulders, S., DE NooiJ, M. (2003): The impact of energy conservation on technology and economic growth, in: Resource and Energy Economics, Vol. 25), pp. 59-79.

Solow, R. M. (1956): A Contribution to the Theory of Economic Growth, in: The Quarterly Journal of Economics, Vol. 70, pp. 65-94.

Solow, R.M. (1957): Technical Change and the Aggregate Production Function, in: Review of Economics and Statistics, Vol. 39, pp. 312-320.

Solow, R. (1974): Intergenerational equity and exhaustible resources, in: The Review of Economic Studies, Vol. 41, pp. 29-45.

Stern, N. (2006): The Economics of Climate Change: The Stern Review, Cambridge University Press, 2006.

Stokey, N.L. (1988): Learning by Doing and the Introduction of New Goods, in: The Journal of Political Economy, Vol. 96, pp. 701-717.

SuE Wing, I. (2003): Representing induced technological change in models for climate policy, in: MIT Joint Program on the Science and Policy of Global Change, No. 102

Sue Wing, I. (2006): Representing induced technological change in models for climate policy, in: Energy Economics, Vol. 28, pp. 539-562.

Thompson, P. (2012): The Relationship between Unit Cost and Cumulative Quantity and the Evidence for Organizational Learning-by-Doing, in: Journal of Economic Perspectives, Vol. 26, pp. 203-224. 
Thornton, R.A., Thompson, P. (2001): Learning from Experience and Learning from Others: An Exploration of Learning and Spillovers in Wartime Shipbuilding, in: The American Economic Review, Vol. 91, pp. 1350-1368.

ToL, R. (2003): Is the Uncertainty about Climate Change too Large for Expected Cost-Benefit Analysis, in: Climatic Change, Vol. 56, pp. 265-289.

ToL, R. (2009): The Economic Effects of Climate Change, in: The Journal of Economic Perspectives, Vol. 23, pp. 29-51.

Turner, K., Munday, M., McGreger, P., and Swales, K. (2012): How responsible is a region for its carbon emissions? An empirical general equilibrium analysis, in: Ecological Economics, Vol. 76, pp. 70-78.

VAN ZoN, A., YETKINER, I.H. (2003): An endogenous growth model with embodied energy-saving technical change, in: Resource and Energy Economics, Vol. 25, No. 1, pp. 81-103.

Verdolini, E., Galeott, M. (2011): At home and abroad: An empirical analysis of innovation and diffusion in energy technologies, in: Journal of Environmental Economics and Management, Vol. 61, pp. 119-134.

Weitzman, M. (1998): Why the Far-Distant Future Should be Discounted at Its Lowest Possible Rate, in: Journal of Environmental Economics and Management, Vol. 36, pp. 201-208.

Weitzman, M. (2001): Gamma Discounting, in: American Economic Review, Vol. 91, pp. 260-271.

Weitzman, M. (2007): A Review of The Stern Review on the Economics of Climate Change, in: Journal of Economic Literature, Vol. 45 (3), pp. 703-724

Weitzman, M. (2009a): Additive Damages, Fat-Tailed Climate Dynamics, and Uncertain Discounting, in: Economics: The Open-Access, Open-Assessment EJourna, Vol. 3, pp. 1-22.

Weitzman, M. (2009b): On Modelling and Interpreting the Economics of Catastrophic Climate Change, in: The Review of Economics and Statistics, Vol. 91, pp. $1-19$

Weitzman M. (2009c), How Should the Distant Future be Discounted When Discount Rates are Uncertain?, in: Harvard University Working Paper.

Weitzman M. (2011), Fat-Tailed Uncertainty in the Economics of Catastrophic Climate Change, in: Review of Environmental Economics and Policy, Vol. 5, pp. 275-292.

Wilbanks, T. (2011): Inducing transformational energy technological change, in: Energy Economics, Vol. 33, No. 4, pp. 699-708. 
Wright, T.P. (1936): Factors Affecting the Cost of Airplanes, in: Journal of Aeronautical Sciences, Vol. 3, pp. 122-128.

\section{Appendix A: Overview of the Studies}

\begin{tabular}{|c|c|c|c|}
\hline Model & Type & Approach & Author(s) \\
\hline DEMETER & IAM & LBD & Gerlagh (2008) \\
\hline $\mathrm{DICE} / \mathrm{RICE}$ & IAM & AEEI & Nordhaus (1994) \\
\hline ENTICE & IAM & & Popp (2004) \\
\hline ENTICE-BR & IAM & R \& D, Backstop & Popp (2005) \\
\hline ETC-RICE & CGE & R \& D, Spillovers & Buonnano et al. (2003) \\
\hline FISCHER2003 & CGE & R \& D & Fischer et al. (2003) \\
\hline FUND & IAM & AEEI, others & Tol $(\mathrm{xxx})$ \\
\hline GEM-E3 & CGE & AEEI & Capros et al. (1997) \\
\hline GOULDER & CGE & R \& D, Spillovers & Goulder and Schneider (1999) \\
\hline GOULDER2 & $\mathrm{ME}$ & LBD, R \& D, Spillovers & Goulder and Mathai (2000) \\
\hline GTEM & CGE & PI & Jakeman et al. (2004) \\
\hline HEGGERDAL & CGE & R\&D, DTC & Heggerdal and Jacobsen (2010) \\
\hline IMAGE & IAM & AEEI, PIEEI & Alcamo et al. (1998) \\
\hline MARKAL-(MACRO) & ES & LBD & Loulou et al. (2004) \\
\hline MERGE2004 & CGE/IAM & AEEI, LBD, Backstops & Manne and Richels (2004) \\
\hline MERGE2008 & IAM & AEEI, PIEEI & Richels and Blanford (2008) \\
\hline MESSAGE-MACRO & ES & LBD & Messner and Schrattenholzer (2000) \\
\hline MIND & IAM & & Edenhofer et al. (2005), Held et al. (2009) \\
\hline MIT-EPPA & CGE & AEEI, Backstops & Jacoby et al. (2006) \\
\hline OTTO2008A & CGE & DTC & Otto and Reilly (2008) \\
\hline OTTO2008B & CGE & DTC & Otto, Löschel and Reilly (2008) \\
\hline PACE & CGE & AEEI, Backstops & Böhringer (1999) \\
\hline PAGE2002 & IAM & AEEI, LBD & Alberth and Hope (2007) \\
\hline POLES & ES & LBD & Kouvaritakis et al. (2000) \\
\hline PRIMES & ES & LBD & Capros and Mantzos (2000) \\
\hline R\&DICE & IAM & R \& D, Spillovers & Nordhaus (1999) \\
\hline TIMES & ES & LBD & Loulou et al. (2005) \\
\hline WITCH2009 & CGE/IAM & R \& D, Backstop & Bosetti et al. (2009) \\
\hline WITCH2011 & CGE/IAM & R \& D, Backstop & Bosetti et al. (2011) \\
\hline
\end{tabular}

Table 2: Applied Models, Related Studies and Technological Change 